\title{
USE OF SLAG IN THE CONSTRUCTION INDUSTRY
}

\author{
Marek ŠAFRÁNEK, Iveta VOZŇÁKOVÁ \\ VSB - Technical University of Ostrava, Ostrava, Czech Republic, EU \\ marek.safranek.st@vsb.cz, iveta.voznakova@vsb.cz
}

https://doi.org/10.37904/metal.2019.976

\begin{abstract}
Despite the use of modern technologies that aim to reduce the environmental impact of manufacturing, industrial production still brings with it some negative phenomena. This mainly relates to the production of waste materials of various types, properties, volumes and also adverse effects on the environment.
\end{abstract}

Most primary raw materials are transformed into waste, so it is essential to maximize the rational use of not only all input materials and energies but also secondary waste materials from production processes. This is especially important since the supply of primary raw materials is not unlimited. The use of waste as a secondary raw material is a beneficial phenomenon for the environment, leading to a reduction in dependence on imported raw materials, and above all, it eliminates the problem of its disposal.

The Republic's strategic goal is to gradually reduce the high raw material and energy intensity of industrial production using low-waste treatment technologies, higher utilization of secondary raw materials and implementation of environmental management such as Circular Economy. According to legislation, the use of waste is preferred to its disposal, with the emphasis being placed on preferential material utilization over other uses of waste.

Recently, all developed nations have devoted much attention to the issues of waste management, and it must be emphasized that the solutions to waste management are in the interest of us all for the future and to the heritage, we leave for future generations.

The article aims to analyze the possibilities of using waste materials from the production of iron in the construction industry and the possible effects on the environment.

Keywords: Slag, construction industry, waste, circular economy

\section{INTRODUCTION}

The article aims to analyze the possible efficient use of waste generated by iron production, to prevent damage to the environment and at the same time to fulfill the idea of Circular Economics. The Institute of Circular Economics defines it as follows: "It is one of the sustainable development strategies that create functional healthy relationships between nature and human society. By perfectly enclosing material flows in long-term cycles, it opposes our existing linear system, in which raw materials are transformed into products, sold and, after their short lifespan, burned or disposed of. [1]

A sustainable development strategy is based on meeting the needs of today's generations so as not to jeopardize the possibilities of meeting these needs for

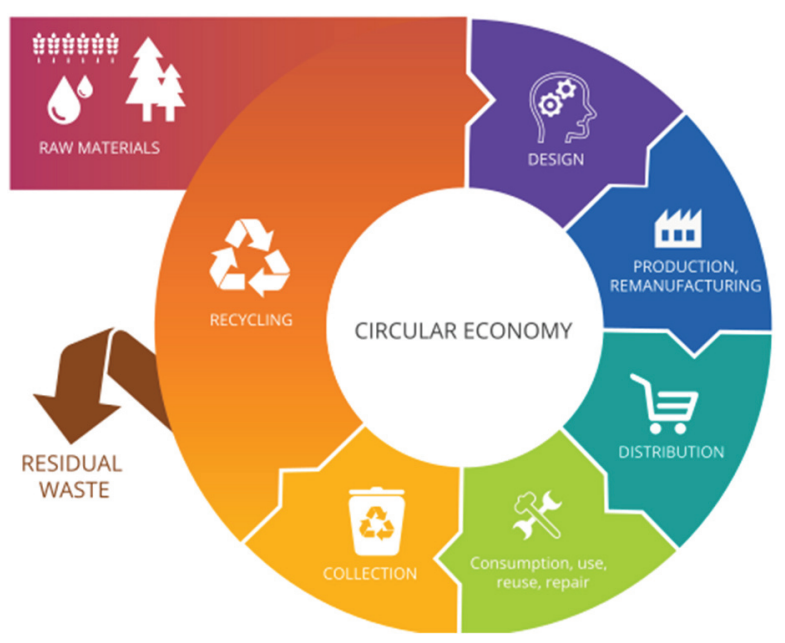

Figure 1 Circular economy. [3] 
future generations. Above all, sustainable development requires a comprehensive approach, in economic and environmental aspects, which combine into a synergy. Synergy is here understood to mean harmony between the social, economic and ecological aspects of human activity. [2]

Figure 1 shows a flow diagram of the principle of a circular economy. [3]

Iron metallurgy is a specific branch of industry concerned with the production of iron-based metals, and their mechanical, chemical and thermal treatment. Unfortunately, this sector is one of the largest environmental polluters. Not only is the production of metals itself a great burden for the environment, but also the large transfers of raw materials and products necessary for production are characterized by massive energy consumption.

An integral part of metallurgical production is a large number of waste products, which can be in solid, liquid or gaseous states, or mixtures of these. Not only do iron production processes contaminate the air, but their resulting waste products also contaminate watercourses and soils.

Main types of recycled waste products in iron metallurgy [4]:

- $\quad$ Agglomerating dust and fly ash concentrate;

- Blast furnace and steel slags;

- $\quad$ Steel and plastic waste;

- $\quad$ Sludge and dross.

\section{ANALYSIS OF RECYCLING AND PROCESSING OF BLAST FURNACE SLAG}

The blast furnace slag is a byproduct of iron production in blast furnaces. From the metallurgical point of view, we divide slags into a blast furnace, steelwork and foundry slags. In the production of iron in blast furnaces, the slag binds all non-ferrous parts of iron ore and prevents iron re-oxidation (floats on the surface). During the so-called blast furnace tapping, blast-furnace slag is drained together with pig iron at $1450{ }^{\circ} \mathrm{C}$. The two materials as separated by their different densities. The amount of slag depends on various factors. On average, $400 \mathrm{~kg}$ of blast-furnace slag is produced per tons of iron produced. This slag consists of 38 to $40 \%$ silica, $40 \%$ calcium oxide, 10 to $12 \%$ magnesium oxide and 7 to $8 \%$ alumina. [5]

The blast furnace slag is removed in large pans and further processed in two ways. It can be cooled in a controlled manner by pouring it into a stream of water to form a granulate - blast-furnace granulated slag. Quality requirements are set out in the ČSN EN 197-1 standard. The second method is slow controlled cooling of blast furnace slag, magnetic separation of iron residues from slag and subsequent production (crushing) of gravel aggregates of various sizes (fractions). Products (aggregates) must meet the requirements of the ČSN EN $12620+$ A1, ČSN EN 13043 and ČSN EN $13242+$ A1 standards. [6]

Figure 2 shows all the types of slag that can be produced. [7]

The blast furnace slag is currently fully recycled. The returning of the useful metal contained in the slag back to the process cycle is especially important. Slags with a useable metal content are returned to the beginning of the

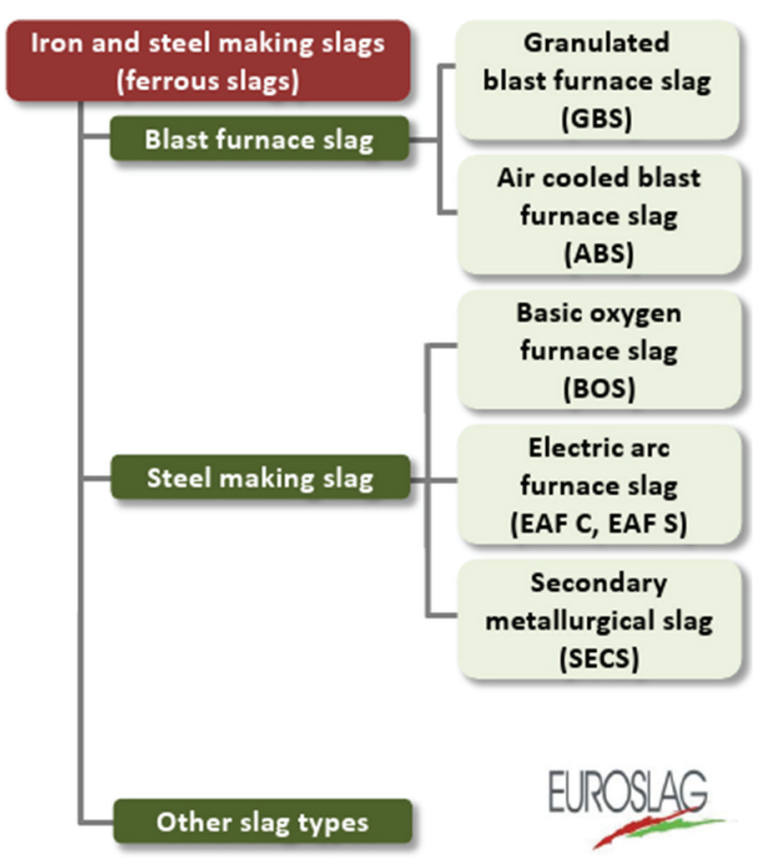

Figure 2 Slag families [7] 
technological cycle. Other slags, which are not returned to the technological cycle, are used mainly in the building industry, or potentially in other sectors. [4]

\section{USES OF BLAST FURNACE SLAG AND ITS PRODUCTS}

For some types of waste, the possibilities of their use have been known for a long time. One of the typical representatives of this group is granulated blast furnace slag, which has been a standard component of mixed types of cement for many years. During the cement production, the slag is added to the fired cement clinker and, with other additives, this mixture is ground into the final products - Portland Slag Cements.

The blast furnace slag also has a significant application in the construction industry as a substitute for the production of gravel for concrete, mortar, road construction, and maintenance, as well as various backfills, coverings, and fillings. Blast furnace slag can also be used as insulation material in the form of slag wool (mineral wool) for thermal insulation. One of the other uses is the production of mineral fertilizers. This is a group of calcium fertilizers with a silicate form of calcium. Such fertilizers are used to improve soil properties and thereby create desirable conditions for calcium nutrition for plants and other uses. [9]

In Europe, the blast furnace slag is primarily used in the cement industry (79\%), the road construction (19\%) and other uses (2\%) (for example, mineral fertilizers) see Figure 3. [7]

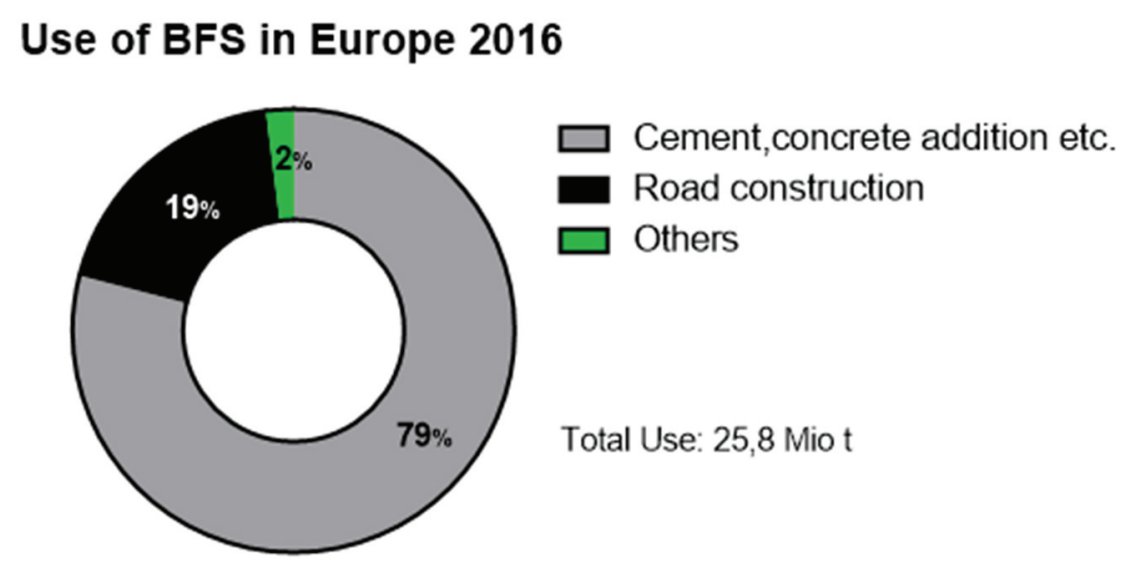

Figure 3 Use of BFS in Europe 2016 [7]

\section{CONCLUSION}

The total production of industrial waste from the manufacturing industry has been on the increase in recent years. In terms of production of industrial waste by region, the Moravian-Silesian Region was the third- largest producer of industrial waste in the Czech Republic in 2017. We are talking about $2,717,781$ tons. Of this figure, 202,762 tons of waste is considered hazardous. Per capita, this represents $1131 \mathrm{~kg}$. This value is the highest quantity of industrial waste products from all regions of the Czech Republic.

Nowadays, when the prices for depositing waste in landfills are increasing, and there is an effort to reduce waste disposal overall, it is desirable to return slag to circulation to the greatest possible extent. However, it should be noted that only a small part of the slag produced is deposited in landfills. In the Czech Republic, the production of by-products (fly ash, slag, clinker) in 2017 totaled 10.3 million tons, of which slag made up over 2 million tons. Only about $2 \%$ of the slag was landfilled, the rest was returned to circulation. Despite this minimal representation, the slag is a problem because it has to be disposed of in special landfill sites, where it is stored in the right conditions to avoid contamination of water and soil. [10] 
One of the possibilities of using the blast furnace slag to its full potential is as a filler in concrete. It acts as a hydraulic component in concrete mixtures and thus increases resistance in aggressive environments. The compressive strength of concretes made from recycled concrete will improve with the addition of silicate admixtures and dispersion additives. A combination using a $30 \%$ slag appears to be a prospective option. Another advantage is that the water flow through a layer or the surface of the concrete is significantly lower, the concrete is sealed and the total surface permeability of the concrete layer is low. Only blast furnace slag that meets the requirements specified in EN 12620 - Aggregates for Concrete, can be used in the concrete. The slag added to the concrete must have the correct chemical composition and non-disintegrating character. [11]

Another way to use the blast furnace slag is in the surface construction sector when the slag aggregate is used for bulk or self-curing foundation layers. Very often in a combination with asphalt in the form of masses for individual road layers.

The blast furnace slag cement or cement combinations have a high resistance to chemical attack, low active alkali content and low hydration heat. Concrete produced from the blast furnace slag cement has high durability due to low capillary porosity, a higher capacity to bind chloride ions and a high electrolytic resistance. These properties support the use of slag types of cemenet for watertight cellars, dams, marine structures, bridges, telecommunication towers, and container structures. The advantage of using the blast furnace slag cement is the significant saving of natural raw materials as well as conserving the energy intensity of cement production, and in particular the reduction of $\mathrm{CO} 2$ emissions.

In the cement production, the use of granulated blast furnace slag instead of clinker reduces overall $\mathrm{CO} 2$ emissions in the process as a result of fuel savings and the prevention of sintering of limestone or other calcareous materials. Calculations made by the German FEHS - Building Materials Research Institute have shown that $\mathrm{CO} 2$ emissions in 2008 were reduced by about 22 million tons in the cement industry in Europe due to the use of 24 million tons of granulated blast furnace slag. [7]

Slag is extremely suitable for road construction because it is durable and has the right material properties - for example, skid resistance. The use of slag makes roads quieter and safer. Another option is to use slag for demanding construction projects such as skyscrapers and bridges and other massive structures where the quality and durability of the material is of great importance. The use of slag is ecological and economically advantageous. The use of blast furnace slag instead of natural rock (limestone or granite) saves not only the energy that may be used to extract natural aggregates but also eliminates the negative impacts of mining, such as effects on biodiversity or environmental degradation. Blast furnace slag contributes positively to the sustainability of all European industry and the fight against climate change. Slag is considered by experts to be the material of the future.

\section{ACKNOWLEDGEMENTS} The work was supported by the specific university research of the Ministry of Education, Youth and
Sports of the Czech Republic in VSB - Technical University of Ostrava No. SP2019/42 and SP2019/62.

\section{REFERENCES}

[1] Institute of Circular Economy. [online]. [cit. 2019-03-05]. Available at: https://incien.org/

[2] The European Unions Approach to Sustainable Development [online]. [cit. 2018-10-27]. Available at: https://ec.europa.eu/info/strategy/international-strategies/global-topics/sustainable-development-goals/euapproach-sustainable-development cs

[3] European Parliament Media Network. European Parliament Media Network [online]. 2015 [cit. 2019-03-04]. Available at: http://epnetwork.tumblr.com/search/circular+economy 
[4] KRET, Ján. Recycling Waste Iron Metallurgy. Ostrava: Vysoká škola báňská - Technical University, 2003. P 42 54. ISBN 80-248-0511-1.

[5] CHRIAŠTEL', Ladislav. Waste Recycling. Bratislava: Slovenská technická univerzita, 2000. P 67 - 75 . ISBN 80 227-1403-8.

[6] KRUPIČKA, Jan. Side Products - Production program. Arcelor Mittal [online]. Ostrava, 2015 [cit. 2019-03-07]. Available at: https://ostrava.arcelormittal.com/pdf/VedlejsiProdukty-VyrobniProgram.pdf.

[7] The European Association Representing Metallurgicall Slag Producers and Processors. Euroslag [online]. [cit. 2019-03-08]. Available at: https://www.euroslag.com/

[8] GEISLER, J. Utilization of blast furnace and steelworks slags. (Reuse of Blast Furnace and BOF Slag) book 1. (1992).

[9] SLIVKA, Vladimír, Vojtech DIRNER a Mečislav KURAŠ. Waste Management II.: Practical Guide. Ostrava: Ministry of the Environment, 2007. P 104 - 133. ISBN 80-248-1245-2

[10] Czech Statistical Office. Čsú [online]. 2017 [cit. 2019-03-27]. Available at: https://www.czso.cz/documents/10180/61546956/28002018.pdf/36b79716-4bee-4e66-96b80298993b2276? version $=1.3$

[11] STEHLÍK, Michal. Produce of Concrete from Modified Building Recycles. Brno: Institute of Building Testing VUT, 2012. 